\title{
Introduction: Setting the stage: The problem with self-sufficiency and the need for collective food security for a global crisis
}

\section{Michael Ewing-Chow and Melanie Vilarasau Slade}

The 2008 food crisis exposed the vulnerabilities of the global food system and their direct impact on human wellbeing. The sudden increase in commodity prices pushed over a hundred million people into chronic hunger. ${ }^{1}$ Some scholars have also suggested that the high prices contributed to the unrest in North Africa and the Middle East which led then to the continuing political instability in the region that started with the Arab Spring. ${ }^{2}$ Though following the crisis the number of hungry is reported to be declining, the Food and Agriculture Organization of the United Nations (FAO) estimates that 805 million people were still suffering from chronic hunger in the period 2012-14. ${ }^{3}$ Instability in the region was also increased by the 2011 food price increases and the sudden perceived failure by regional governments to provide essential food security to the population. ${ }^{4}$

As if the devastating effects of food price volatility on the most vulnerable and the current inequality of food distribution together with the potential for increasing political instability were not sufficient incentives for action, the world's population is growing by around 77 million people every year. By 2050, there will be more than nine billion people reliant on the earth's natural resources. ${ }^{5}$ It is estimated that to feed the global population will require 60-70 per cent more food from the 3 per cent of the

${ }^{1}$ FAO estimates set the figure at approximately 115 million, principally due to higher food prices. See FAO, The State of Agricultural Commodity Markets, (FAO, 2009).

2 M. Lagi, K. Z. Bertrand and Y. Bar-Yam, 'The Food Crises and Political Instability in North Africa and the Middle East', New England Complex Systems Institute (September, 2011) available at http://necsi.edu/research/social/food_crises.pdf.

${ }^{3}$ FAO The State of Food Insecurity in the World 2014 (FAO, 2014).

4 Above fn 2.

${ }^{5}$ United Nations, World Population Prospects: the 2012 Revision (UN, 2013). 
world's surface which is arable land. ${ }^{6}$ This makes it likely that we will face more crises than less in the future particularly when production disruptions caused by climate changes are anticipated.

The world will also undergo rapid urbanisation accompanied by increases in income levels and changing food preferences. McKinsey estimate that as urbanisation proceeds on an unprecedented scale, new and expanding cities could displace up to 30 million hectares of the highest quality agricultural land by $2030 . .^{7}$ Another concern is that over 80 per cent of available arable land is subject to high political risk and/or infrastructure challenges: a potential deterrent to the much-needed investment in agriculture. ${ }^{8}$ Globally there is forecast to be a 40 per cent shortfall in sustainable water by $2030,{ }^{9}$ and agriculture accounts for around 70 per cent of global water use. ${ }^{10}$ Climate change is now poised to bring its own set of challenges to a sector which remains highly susceptible to, and dependent on, favourable and predictable weather conditions.

This dire situation is generally acknowledged. However, despite the urgent need for an effective response to these challenges, there is little consensus as to the appropriate policy mechanisms required to bolster the resilience of global food systems.

A critical point of contention is the role which international trade should play in the pursuit of food security and, conversely, the extent to which self-sufficiency policies can be relied upon to achieve food security globally. ${ }^{11}$ Given the systemic impact of national food security policies, the existence of such fundamental divisions is of grave concern and threatens to undermine the pursuit of collaborative solutions.

One of the few areas of consensus among food security specialists is the complexity of this field and the need for a multidisciplinary approach to its study, which takes into account the broad range of stakeholders involved in our global food system. This book aims to contribute to the debate on the topic of international trade and food security, and to do so from a multidisciplinary perspective. It will take as its focus the Asia region, with a

${ }^{6} \mathrm{UN}$ estimate cited in several sources including http://unesdoc.unesco.org/ images/0021/002154/215492e.pdf and http://www.fao.org/fileadmin/templates/wsfs/docs/ expert_paper/How_to_Feed_the_World_in_2050.pdf.

7 McKinsey Global Institute Resource Revolution: Tracking global commodity markets (MGI, 2013).

8 Ibid.

9 See for example: http://unesdoc.unesco.org/images/0023/002318/231823E.pdf.

10 See for example: http://www.oecd.org/tad/sustainable-agriculture/49040929.pdf.

11 This includes divisions among international organisations dealing with food security issues. A high-profile example of this division can be found in the unresolved debate between former WTO head Pascal Lamy and former UN Special Rapporteur on the Right to Food Olivier de Schutter. 
particular emphasis on the ASEAN region where national self-sufficiency policies co-exist with regional agreements to enhance food security, thus creating an ideal case study to explore tensions between national and regional or 'collective' approaches to food security particularly as they relate to developing countries where some of the most vulnerable live.

Cognisant of the pivotal role which legal systems can play in supporting systemic solutions to the food security challenge, in October 2013 the Centre for International Law (CIL) at the National University of Singapore, supported by the WTO Chairs Programme, hosted an international conference on food security and invited contributions from specialists in a variety of fields, including economists, policymakers, lawyers and academics, all with a particular interest in Asia. The Food Security Conference was held conjunctively with the $2^{\text {nd }}$ Singapore Trade Dialogue in October 2013 and was attended by senior Asian trade officials prior to the $9^{\text {th }}$ World Trade Organization (WTO) Ministerial Conference held in Bali, Indonesia in December 2013. The outcomes of the CIL Food Security Conference were the starting point for this publication, through which we hope to encourage and contribute to a constructive discussion on the ways in which food security can be strengthened across the Asia region and globally.

In Asia, two of the principal regional food security challenges are pricing volatility and the impact of environmental changes including climate change. This book addresses these challenges.

Common to each of the contributions are some terms and fundamental assumptions which will be outlined here. These include our understanding of 'food security'; its critical link to 'rice security' (the main staple crop) in Asia; the impact of the 2008 food crisis and of the food security policies implemented in its aftermath.

We trust that, with this context in place, the views, analysis and conclusions of each of the contributing authors will be more easily understood.

\section{FOOD SECURITY}

\section{What is Food Security?}

Food security exists when all people, at all times, have physical and economic access to sufficient safe and nutritious food that meets their dietary needs and food preferences for an active and healthy life. This definition, agreed at the 1996 World Food Summit ${ }^{12}$ was adopted by the FAO and

12 Rome Declaration on World Food Security, done at Rome, 13 to 17 November 1996. The World Food Summit where the Declaration was agreed took place from 13 to 17 
has become the normative definition of food security. Intrinsic to this definition are the elements of availability, utilisation, and access, along with the need for stability of all these elements over time: a requirement particularly relevant in the era of pricing instability in the global food market. ${ }^{13}$

The transition from the concept of national food security to that of individual food security has been a gradual one, in which the focus shifted from the State to the individual ${ }^{14}$ much as it did in the shift between the theory of mercantilism to that of comparative advantage and free trade.

The World Food Conference (1974) defined food security in terms of food supply, ensuring the availability and price stability of basic foodstuffs at the international and national level 'Availability at all times of adequate world food supplies of basic foodstuffs to sustain a steady expansion of food consumption and to offset fluctuations in production and prices.' Put simply, the term was used to describe whether a country had access to enough food to meet dietary energy requirements. The potential gulf between availability of food at national level and access to food by individual households within a given country was acknowledged in the 1980s, most notably in the literature of Amartya Sen. The concept of food security is therefore far from being a static one. ${ }^{15}$

Nonetheless, this book will take as a starting point the 1996 definition of food security together with its four main elements (i.e., availability, stability, utilisation, and access). While this definition is not without its limitations, it remains the definition which has generated the most international consensus. Further, it highlights that progress towards the achievement of global food security must be measured on the basis of whether each individual enjoys food security now and in the future. Logical though this may seem, as we will explore further in this book,

November 1996. This historic event, convened at FAO headquarters in Rome, comprised five days of meetings at the highest level with representatives from 185 countries and the European Community. For more information see: http://www.fao.org/wfs.

13 In P. Pinstrup-Andersen, Food Price Policy in an Era of Market Instability: A Political Economy Analysis. (Oxford University Press, 2014).

14 See Amartya Sen, Poverty and Famines: An Essay on Entitlement and Deprivation (Clarendon Press, 1981). This led to the FAO redefining food security in 1983 as: 'Ensuring that all people at all times have both physical and economic access to the basic food that they need.'

15 Indeed, the concept remains fluid: the FAO's The State of Food Insecurity in the World 2001 (Rome: FAO, 2001) provides the following definition: 'Food security [is] a situation that exists when all people, at all times, have physical, social and economic access to sufficient, safe and nutritious food that meets their dietary needs and food preferences for an active and healthy life.' As described in a subsequent report by the FAO '[t]his new emphasis on consumption, the demand side and the issues of access by vulnerable people to food, is most closely identified with the seminal study by Amartya Sen. See Trade Reforms and Food Security: Conceptualising the Linkages (FAO, 2003). 
current food security policies focus on ensuring self-sufficiency on a national level rather than - and at times to the detriment of - achieving food security for 'all people' globally.

\section{Food Security in Asia: Rice Security is Food Security}

Rice is a highly sensitive product in Asia. Over 90 per cent of the world's rice is produced and consumed in the Asian region. Until recently, the trend in Asia showed an increase in production and export, but a decrease in consumption ${ }^{16}$ as growing prosperity and urbanisation contributed to a decline, particularly in middle- and high-income Asian countries like Japan and the Republic of Korea, in favour of more Western diets. More recently it seems this declining trend may have stabilised or even reversed, in particular in China, India and Indonesia, contributing to a rise in global consumption. ${ }^{17}$

Nevertheless, according to FAO statistics, in 2007 more than half of the ASEAN countries still took around 50 per cent of their daily calories from rice. ${ }^{18}$ Further, approximately one-quarter of the Asian population is still poor and there is considerable unmet demand for rice in countries such as Afghanistan, North Korea, Nepal and Vietnam. It is in these countries that rice consumption could grow faster. ${ }^{19}$ This means:

Increasingly, rice is consumed by the poor, who usually must buy most of their rice in rural and urban markets. Almost by definition, having a surplus of rice to sell to the market raises a family above the poverty line in most Asian countries. This reality, of course, makes rice more, not less, important to food security in Asia. ${ }^{20}$

16 S. Ito, E. Wesley, F. Peterson and W. Grant, 'Rice in Asia: Is it becoming an inferior good?' (1989) 71 American Journal of Agricultural Economics at pp. 32-4.

17 Based on PSD online database (USDA) and FAOSTAT population database (FAO) cited in Samarendu Mohanty 'Trends in global rice consumption' in IRRI publication 'Rice Today' January-March 2013 available at http://irri.org/rice-today/ trends-in-global-rice-consumption.

18 This includes Cambodia, Indonesia, Laos, Myanmar, Philippines, Thailand and Vietnam. In particular, about 64 per cent of the daily calories intake is from rice in Cambodia and Laos. Source: Authors' own calculations based on FAO Statistics.

19 M. K. Papademetriou, 'Rice production in the Asia-Pacific region: Issues and perspectives', in M. K. Papademetriou, F. Dent and E. Herath (eds), Bridging the Rice Yield Gap in the Asia-Pacific Region, RAP Publication: 2000/16 (FAO, 2000): http://www.fao. org/docrep/003/x6905e/x6905e04.htm\#RICE\%20PRODUCTION $\% 20 I N \% 20$ THE $\% 20$ ASIAPACIFIC $\% 20$ REGION $\% 20$ ISSUES $\% 20$ AND $\% 20$ PERSPECTIVES $\% 20 \mathrm{M} . \mathrm{K} . \% 20$ Papademetriou*.

${ }^{20}$ C. P. Timmer, 'The changing role of rice in Asia's food security', in Food for All: Investing in Food Security in Asia and the Pacific - Issues, Innovations, and Practices (Asian Development Bank 2011). 
Southeast Asia, the main focus of this book, is heavily dependent on rice: in 2007, rice accounted for 85.9 per cent of cereal production and 32 per cent of the total agriculture. ${ }^{21}$ The ratio of production to domestic utilisation for ASEAN as a whole in 2014 is estimated at 120.82 per cent. While in aggregate ASEAN is a rice self-sufficient region, some countries in the region still need to import rice for their own consumption. ${ }^{22}$

Worryingly, the potential for volatility of the price of rice across Asia is still high. Indeed, pricing volatility in food markets has been described as the 'new normal' and rice pricing in particular remains highly vulnerable to political decisions by regional governments. ${ }^{23}$

The combination of this volatility with reliance on this staple crop by the poorest sectors of society in Asia makes a large part of the Asian population, especially those in the least-developed countries, particularly vulnerable to spikes in the price of rice. Together these factors mean that, at present, achieving food security in the Asian context is inextricably linked to achieving a state of rice security.

\section{Challenges to Food Security: The 2008 Food Crisis}

The ability of the current food system to ensure collective food security was severely tested by the 2008 food crisis, revealing a number of serious deficiencies and systemic flaws.

In 2008 the upturn in international food prices that began in 2006 escalated to a surge of food price inflation on a global scale. The crisis has been described as follows:

As food prices began to rise, commodity-exporting nations placed export restrictions on price-volatile crops grown nationally, such as rice, to protect their food security. Export restrictions, reduced import tariffs and other trade distortions drove up international commodity prices, resulting in shortages of food on the global market and causing panic for many emerging economies suffering from a dearth in natural resources. ${ }^{24}$

Additional factors included an increased use of food crops for biofuel, high oil prices, an inflow of speculative funds into the agricultural com-

${ }^{21}$ Ibid., at Table 1 rice and the structural transformation: 1961-2007.

22 ASEAN Food Security Information System Project, Report on ASEAN Agricultural Commodity Outlook No. 12, June 2014.

${ }^{23}$ See in particular Clarete et al Rice Trade and Price Volatility: Implications on ASEAN and Global Food Security ADB Economics Working Paper Series No. 368, (Asian Development Bank 2013).

24 B. Robertson and P. Pinstrup-Andersen, 'Global land acquisition: neo-colonialism or development opportunity?' (2010) 2(3) Food Security, at pp.271-83. 
modity futures market and an increasing demand for food in emerging economies such as China and India which generated increased demand for feed. The FAO contends that all these factors contributed to the spike in food prices and that 'it was the combination of them that was crucial'. ${ }^{25}$

Whatever its causes, the effect on commodity price levels was dramatic. FAO figures show that while there was an increase of 9 per cent in the price of rice from 2005 to 2006 and 17.5 per cent from 2006 to 2007; from 2007 to 2008 , the rice price skyrocketed by 83 per cent. ${ }^{26}$ The effect on global food security was no less dramatic. The FAO calculates that in 2007 and 2008, mainly because of high food prices, an additional 115 million people were pushed into chronic hunger. ${ }^{27}$

In most cases the short-term policy responses adopted to deal with the food price spike fitted into longer-term policy frameworks and were driven by long-term policy objectives, such as national food security or stabilisation of farm revenues. ${ }^{28}$ Unfortunately, these policies tended to aggravate the food price spike globally rather than alleviate it. The dramatic effect of the 2008 food price spike on the rice market is a good illustration of the effect of national self-sufficiency policies on global prices. By way of a short summary of events in the rice market, India's decision in October 2007 to ban rice exports, except for Basmati, was quickly followed by Vietnam and other major players, and speculation that Thailand would follow suit. This had an immediate impact on prices leading to panic purchases of rice, especially by large rice importers such as Philippines, which further aggravated the situation. Speculators, sensing a crisis, then swooped in to take advantage of this, leading to even higher prices. ${ }^{29}$ The International Food Policy Research Institute (IFPRI) concluded that 'three-quarters of the increase in the price of rice occurred in 2008 -almost certainly because of adverse policy responses, such as export bans, from some major exporters' ${ }^{30}$

Yet the food security policies of many food-producing nations remain premised on the assumption that the only way to guarantee their national

25 FAO, fn 1 above.

26 See FAO Rice Price Update (January 2010), online: http://www.fao.org/es/esc/en/15/70/ highlight_533.html.

27 FAO, above fn 1.

28 D. Jones and A. Kwiecinski, 'Policy Responses in Emerging Economies to International Agricultural Commodity Price Surges', OECD Food, Agriculture and Fisheries Working Papers, n. 34, (OECD Publishing 2010).

29 See, inter alia, Dawe and Slayton, 'The World Rice Market Crisis of 2007-2008' in David Dawe (ed.), The Rice Crisis: Markets, Policies and Food Security (London, (FAO and Earthscan 2010), pp.18-24.

30 D. Headey and S. Fan, Reflections on the Global Food Crisis, International Food Policy Research Institute (IFPRI) monograph 165 (IFPRI, 2010) at p.32. 
food security is to focus on achieving some level of self-sufficiency. They believe that if they do not produce enough domestically, during a shortage, no one else will be willing to trade food with them or will only trade food at exploitative prices. As a result, the agricultural policies of many nations focus on providing their domestic producers with increased incentives to produce food domestically by way of subsidies and/or protecting them from foreign competition through barriers such as quotas, tariffs and standards targeted to limit foreign imports.

The problem with this response is that it fails to fully appreciate the systemic impact such policies have on global food production. Incentives in one nation may create disincentives in others to produce food. For example, subsidies may distort food prices sufficiently to reduce the food production in the country importing the subsidised food. With the increasingly unpredictable weather patterns caused by climate change (anthropogenic or otherwise), focusing on domestic production alone seems to be a rather more risky strategy than previously imagined. Indeed, the 2008 food price spikes were triggered by unanticipated weather affecting crop yields. The extended drought in the Murray-Darling region of Australia reduced rice yields by 98 per cent, ${ }^{31}$ unseasonal rains wiped out crops in Kerala, India, ${ }^{32}$ and Cyclone Nargis destroyed the rice fields in the Irrawaddy Delta of Myanmar. ${ }^{33}$ Recently, on World Food Day, Christiana Figueres, Executive Secretary of the UN Framework Convention on Climate Change (UNFCCC), said:

Aside from permanent shifts in climatic conditions which will affect farming, climate change is causing more and more extreme weather, for example tropical storms, floods and droughts which can push subsistence farmers and others living in food insecurity into dire circumstances. ${ }^{34}$

We can no longer predict with certainty the likelihood of food production of any particular nation or region.

31 'Drought in Australia reduces Australia's rice crop by 98 percent' The New York Times, 17 April 2008 see http://www.nytimes.com/2008/04/17/business/worldbusiness/17warm. html?n=Top/News/Science/Topics/Global\%20Warming.

32 'Crops lost due to unseasonal rains in Kerala' The Economic Times, 8 April 2008 at http://articles.economictimes.indiatimes.com/2008-04-08/news/28439839_1_unseasonalrains-paddy-production-crops.

33 'Cyclone fuels rice price increase', BBC News, 7 May 2008 at http://news.bbc.co.uk/1/hi/ business/7387251.stm.

34 UN Press Release, 16 October 2013, Efforts to end world hunger must be aligned with tackling climate change warns UN's top climate change official Christiana Figueres on World Food Day available at: http://unfccc.int/files/press/press_releases_advisories/appli cation/pdf/pr20131610_m4c_food.pdf. 
It may even be that geographical borders in an increasingly interconnected and unpredictable world are becoming less helpful parameters for food security policymaking. The rise of global value chains (GVCs) have resulted in many food production systems being increasingly influenced by multinational corporations (MNCs) rather than individual nations. These MNCs straddle multiple nations and have sophisticated chains of production dependent on the incorporation of different inputs from a number of different sources. A break in the chain where it is weakest may trigger a cascade of events that national food security policies alone may not be able to control.

Even if a nation were sufficiently large, controlling and isolationist to organise its food security policies in a way that secured its own security, recent events in the Middle East have once again highlighted the difficulty of securing the borders from people fleeing crises. Climate change and food shortages will inevitably cause major movement of people and we can anticipate that no one nation will be able to manage the attendant problems on their own.

All of these new factors of climate change, GVCs and potential growth in the number of political refugees and climate migrants suggest that we need to rethink food security. We can no longer think of it as national self-sufficiency but rather instead we need to understand the problem as one of global collective food security. We need to understand how trade, investments and information may all be able to play a role in addressing this major concern.

Too often, governments interpret 'all people' to be limited to their territory and citizens, ignoring the universal scope of the concept of food security and the systemic impact of national food security policies. To bring this back to the fore, we, the Editors developed the term 'collective food security' to refer to a state where the systemic impact of national policies is acknowledged and the focus shifted to ensuring food security can be achieved globally rather than nationally.

Just as trade is an essential element of food security policy; it is also an essential requirement of a sustainable global food trade system that it enables the achievement of food security for all. This is not a selfless endeavour but rather a fundamental requirement in order to ensure the viability and sustainability of national food security policies.

We suggest therefore that the debate should be refocused: In a globalised food system, compliance with WTO rules may not be an undue restriction but rather a virtuous discipline, which reduces volatilityenhancing trade distortions. The 2008 food price spikes were aggravated by a cascade of export restrictions by major crop exporters that increased panic and thereby unilateral responses. A collective response to future crises is needed and may be possible even under the current WTO rules. 
This book will endeavour to explore this premise in three parts:

The first section presents the realities of the current global food trade system. It explores international trade rules, and provides an overview of GVCs in agriculture in an effort to place current food security initiatives in their global context. It then explores national and regional food security initiatives in ASEAN, examining the contrasting efforts towards greater cooperation and greater self-reliance, and assessing the impact of international trade rules on these initiatives. Thus, in Chapter 1, Evan Rogerson and Diwakar Dixit describe the WTO's contribution to the liberalization of trade in food, from the Uruguay Round to the latest Bali Decisions. In Chapter 2 Julia Tijaja provides an overview of Global Food Chains, exploring trends that could impact on national food security policies. Chapters 3 and 4 explore regional tensions in ASEAN between national and regional food security. Roehlano M. Briones, Michael Ewing-Chow and Melanie Vilarasau Slade separately examine these food security initiatives, contrasting efforts towards greater regional integration with national self-sufficiency initiatives, and exploring the impact that WTO rules.

This second section focuses on one of the most significant challenges faced by the current system: market shocks and pricing volatility. It explores the causes and effects of pricing volatility in agriculture (across sectors including rice and dairy) and the potential for policy solutions, including stockholdings, transparency initiatives and market-based mechanisms. In Chapter 5, C. Peter Timmer sets out the case for greater research into public stockholdings as a food security tool; in Chapter 6 Ramon L. Clarete assesses the impact of self-sufficiency policies in ASEAN and proposes policy solutions to the threat of pricing volatility; and in Chapter 7 James McVitty of Fonterra provides a private sector perspective and sets out the case for market-based risk management tools.

The third section focuses on the most significant challenges the current system is likely to face in future, including climate change and resource shortages. The final section then assesses the role which international law can play in addressing these challenges. In Chapter 8 Lee Ann Jackson focuses on the potential supply side constraints that could impact food security and highlights the advantages of a resilience-focused approach to agricultural investment and its critical importance to the effectiveness national food security policies. In Chapter 9 J. Jackson Ewing focuses on the environmental challenges facing Southeast Asia and their likely impact on food security in order to assess the effectiveness of various food security policy options. In Chapter 10 Melanie Vilarasau Slade will examine whether reform of international law is required in order to support collaborative efforts to address future food security challenges.

Finally, this book will look towards the future and assesses the potential 
for improvement of the current international trade system from a food security perspective. In doing so it will seek to explore whether solutions are possible within the current system and what initiatives are required to create the conditions under which collective food security can be achieved. In Chapter 11 Clemens Boonekamp looks in particular at how international trade rules can be improved to give greater priority and effect to the WTO's stated aim to contribute to global food security through trade liberalization. In this book's Conclusion, the Editors will seek to address the lessons learned and map out the path towards collective food security. 
Michael Ewing-Chow and Melanie Vilarasau Slade - 9781785361890 Downloaded from PubFactory at 04/26/2023 08:19:09AM 